\title{
The Effect of Disclosure of Financial Report and Managerial Ability on Earnings Management with Audit Quality as a Moderating Variable
}

\author{
Luh Gita Andini Artika Putri $^{1^{*}} \quad$ I. D. G. Dharma Suputra ${ }^{2}$ \\ 1. Magister Progam in Accounting, Faculty Of Economics And Business, University of Udayana \\ Jl. PB Sudiman Denpasar, Indonesia \\ 2. Faculty Of Economics And Business, University of Udayana Jl. PB Sudiman Denpasar, Indonesia
}

\begin{abstract}
This study aim to obtain empirical evidence about the effect of disclosure of financial report and managerial ability on earnings management with audit quality as a moderating variable. This research was conducted for the period of $2012-2016$, with a sample of 375 observing companies. The measurement of disclosure of financial report can be proxied by a disclosure index consisting of 33 voluntary disclosure items. Managerial ability used measurement of Data Envelopment Analysis (DEA). Audit quality used measurement of perceptions of the quality of financial reports auditor by Big Four accounting firms or non-Big Four accounting firms. The last, earning management used Jones's modefication measurement. The analysis used Moderated Regression Analysis (MRA). The test result shows that disclosure of financial report has an effect on earnings management, but had not significant effect to managerial ability. Futhermore, audit quality is moderated the effect of disclosure of financial report on earnings management, but is not able to moderate the relationship between managerial ability and earnings management.
\end{abstract}

Keywords: disclosure of financial report, managerial ability, audit quality, and earnings management.

DOI: $10.7176 /$ RJFA/10-2-04

\section{Introduction}

Earnings management practice occurs because of the opportunistic behavior of managers who attempt to increase or decrease profits in the company's financial report for certain purposes, thus increases the assumption of incredibility agints company managers and the integrity of an accountant. Earnings management will occur when managers have the motivation to mislead financial statement users by applying accounting policies or manipulating activities in financial reporting (Velayutham, 2014). Sukartha (2008) added that according to agency theory, there is a working relationship based on an efficient contract between the principal and the agent. The situation when an efficient contract does not occur, namely the condition of subordinates having more diverse and complete information than the owner or boss is called asymmetric information. There are three conditions that create transparency in the financial statements, namely: 1) financial report makers (managers) have more information than investors; 2) the objectives of the manager are not the same as those of the investor; 3 ) opportunities in accounting and audit rules that can be utilized (Kurniawati, 2011).

The condition of the company in a period are presented in the financial statements (Wirawati \& Putri, 2018). Some cases of earnings management, the Japanese company Toshiba in 2015 carried out 21 accounting forgery cases as of March 31, 2014 related to construction work, which made the company's revenue increase. The miscalculation was announced at 54.8 billion yen, but it is estimated that seven years of bookkeeping fraud reached 150 billion yen. These events caused Toshiba's shares to decline by around 20\%, Toshiba's chief executive and president HisaoTanaka had retired. In Indonesia, Bapepam reported that in 2002 PT Kimia Farma made a recording and sales error for the accounting period of 2001, resulting in profits overstated of Rp 32.69 billion. PT Indofarma in 2004 made a mistake in recording inventory in the auditing process, resulting profits overstated of Rp. 8.87 billion (www.bapepam.go.id). The manager's thinking will determine the measurement and accrual direction of the financial statements, so that it will be a gap for manipulation of the financial statements. Several factors that can influence the occurrence of earnings management, are the disclosure of financial report and management ability.

The more complete financial statements or using full disclosure will reduce asymmetric information and close the possibility for managers to make earnings management. Information in the financial statements will be revealed less by companies that do earnings management so that their actions are not easily detected. The effect of disclosure of financial report on earnings management has been proven by previous studies on 11 banks in Nigeria by (Uwuigbe, 2017), the results of his research indicate that disclosure of financial report has a negative effect on earnings management. Supported by researches (Jatiningrum, Abdul-hamid, Muse, \& Popoola, 2016); (Kurniawati, 2011); (Riahi \& Arab, 2011); and (Benardi, Sutrisno, \& Assih, 2008). But unlike the results obtained by (Consoni, Colauto, \& Lima, 2017) who conducted research on 66 Brazilian companies, found that voluntary disclosure had no effect on earnings management. There are inconsistencies in the results of the 
influence of disclosure of financial reports on earnings management.

A manager can make the right decisions for the company's progress if it has high experience, ability and integrity. A manager is said to be capable or capable when faced with problems of decision making, and the decisions he makes make the company more efficient (P. Demerjian, Lewis, \& Mcvay, 2012). Conditions where managers have hidden information and are not known by shareholders, and this information can be used by managers for their personal interests. A manager who is capable of knowing the internal company and can identify opportunities from accrual reports. this will be used to maximize bonus revenue (Isnugrahadi \& Kusuma, 2009). The effect of managerial ability on earnings management has been demonstrated by studies conducted (Lande, 2014); (Wicaksono \& Yuyetta, 2013); (Utami \& Syafruddin, 2013); and (Isnugrahadi \& Kusuma, 2009). But the results of the study (Septiana, 2013) and (Purwanti \& Rahardjo, 2012) were not in line which found that there was no effect of managerial ability on earnings management.

Auditing is an indicator of stakeholders to believe in the fairness of the annual report presented by the internal company. Auditors are made as external parties who oversee management actions. Audited financial statements can be trusted if carried out by high-quality auditors and are believed to have the ability to prevent earnings management. Auditors who have high quality can give influence to the company in order to fully disclose financial statements so as to reduce earnings management (Okolie, 2013).

The reason for attractive earnings management to be examined is the behavior of managers when reporting on their business activities and the possibility of the emergence of managers' motivation to report incorrect financial statements. This research is motivated by research gaps and company demands to disclose information so as to make it easier for users of financial statements to assess company performance and avoid opportunistic behavior

The influence caused by the level of financial statement disclosure and managerial abilitys in earnings management is moderated by audit quality, the auditor as an external party is considered to reduce information disruption between the agent (manager) and the principal (shareholders). The auditor assesses the annual report instead of restating the financial statements. Good auditor quality is expected to reduce earnings management practices.

\section{Literature}

\subsection{Agency Theory}

Jensen \& Meckling (1976) states that agency relations are the relationship between principal and agent, where the principal employs agents to provide services and delegates power to the agent to make decisions on behalf of the principal based on a nexus of contract. Agency relationships require agents to account for their efforts to shareholders by providing periodic reports to the principal regarding the business being carried out and superiors in this case stakeholders will assess the manager's performance through the annual report that has been done. The purpose of agency theory is to create efficient contracts between shareholders and management. Cooperation agreements between principals and agents contain rules regarding the way the distribution of results between the two parties, in the form of profits or in the form of losses, returns and risks in every business transaction carried out._Sukartha (2008) describes the terms of an efficient contract, namely: 1) There is symmetrical information between the agent and the principal, namely the situation in which management and shareholders have the same quality and quantity of information so that no information is not presented that can be used to personal interests, and 2) The service benefits obtained by management as an agent are certain. Based on human nature, conflicts of interest between management and owners make agents present untrue information. Endrianto (2010) revealed that efforts to overcome or reduce agency problems by generating agency costs. The essence of this theory is the right contract design to align the interests of management and shareholders when there is a conflict of interest.

\subsection{Earning Management}

Earnings management is an opportunistic action taken by managers by deciding an accounting policy, this makes managers able to increase or decrease profits based on personal interests (Nuryaman, 2009). Earnings management occurs when agents (managers) implement their decisions in annual reports and change transactions so that they show information that is not in accordance with the company's actual performance. It was concluded that earnings management is management intervention on financial statements, in the form of choices made by management on accounting events to achieve certain objectives, so as to reduce the credibility of financial statements and cannot be accounted for. The asymmetry of the information contained in the financial statements can occur at the annual report that uses an accrual basis. An accrual basis can create an opportunity for an agent to choose an accounting policy so that it will affect the income he will report to the principal, the accrual basis records all transactions according to the transaction date, not according to cash receipts, making it easier for managers to use earnings management. Accruals not only reflect the choice of accounting methods but also the effect of the time of recognition of income and expenses, impairment, and changes in accounting estimates (Islam et al. 2011). Discretionary accruals are used as indicators of earnings management practices because they 
are managerial interventions in the financial reporting process and the right of managers to make or decide policies that will affect financial statements, generate profits and apply accounting principles chosen by manager

\subsection{Disclore of Financial Reports}

The level of disclosure is all information presented in annual reports and includes footnotes, subsequent events, management analysis of the company's going concern, financial and operating forecasting, and additional notes on financial statements. Based on the standard requirements financial statements can be divided into two. In Indonesia, disclosures in annual reports are mandatory and voluntary, and are regulated in PSAK No.1. The purpose of disclosure is to provide significant and relevant information to users of financial statements. The disclosure of financial reports in this study is based on the index available in the annual report (Benardi et al., 2008). According to (Hendriksen \& Breda, 2002) in (Purwanti \& Rahardjo, 2012) there are three levels of disclosure, namely as follows: 1) full disclosure; 2) fair disclosure; and 3) sufficient disclosure (adequate disclosure).

\subsection{Managerial Ability}

The ability of agents to choose policies and implement these policies so as to bring companies to be more efficient is called managerial ability (Demerjian, Lev, and McVay 2013). A capable and professional manager has more and more extensive knowledge regarding the company. Managerial ability is one of the factors that drive the company's operational efficiency, the ability of agents can be seen and measured through the level of efficiency that managers can achieve when using resources. Managerial ability are measured by manager's efficiency when using company resources in order to create optimal output and create a positive impact on financial reporting quality that affects the company's future. Assets, capital and labor owned by the company will be used to create maximum output in the form of income ( $\mathrm{Li}, 2015)$. Managers have an obligation to convey company achievements through annual reports. Managers use judgment to make financial statements, in the application of accrual accounting, managers are allowed to choose the accounting method to be used.

\subsection{Audit Quality}

Audit quality is defined as the possibility of an auditor to find a misstatement that is material in the annual report of the auditee and report it if the auditor finds the error in the stakeholder (De Angelo, 1981). It can be concluded that audit reports are of high quality when an auditor is able to demonstrate material misstatements and report them. Some research results support the statement that large accounting firms will produce audit reports that are better qualified than small accounting firms (Gerayli, Yanesari, \& Ma'atoofi, 2011), so the quality of an auditor is also a key factor in whether or not earnings management in a company. An auditor can be said to be quality if he is able to find a manager who is material and able to provide an opinion that is truly appropriate in accordance with the audited financial statements, not only relating high fees, but being neutral on the financial statements which are his duty (Kirana \& Hasan, 2016) High quality auditors find it easier to find accounting practices that are questioned by clients and report material irregularities than low quality auditors. Audit reports with high quality will attract investors, Big Four accounting firms are believed to have a greater ability to limit earnings management practices.

\section{Hypothesis}

$\mathrm{H}_{1} \quad$ : Disclosure of financial report has a negative effect on earnings management.

$\mathrm{H}_{2}$ : Managerial ability have a positive effect on earnings management.

$\mathrm{H}_{3}$ : The higher the level of disclosure of financial report with high audit quality, the lower the intensity of earnings management.

$\mathrm{H}_{4} \quad$ : The higher managerial ability with high audit quality, the lower the intensity of earnings management.

\section{Research Methods}

The population in this study are manufacturing companies that were delisted onf the Indonesia Stock Exchange and the time period was set for the period 2012 to 2016 . For the determination of the sample, purposive sampling technique was used. The reason for choosing this sample technique is to obtain a representative sample so that it can be in accordance with the provisions that have been made into a criterion by the researcher. The provisions of the researcher are divided into four things; 1) manufacturing companies listed on the IDX for the 2012 to 2016 period; 2) manufacturing companies that did not experience delisting in the 2012 to 2016 period; 3) manufacturing companies that submit annual reports in Rupiah currency from 2012 to 2016; 4) manufacturing companies that submit complete annual reports for the period 2012 to 2016.

\subsection{Measuring Earnings Management}

Earnings management can be measured through discretionary accruals (DACC) which are calculated by 
eliminating total accruals (TACC) and nondiscretionary accruals (NDACC). Discretionary accruals are calculated using the Modified Jones model. The Modified Jones Model equation as follows:

Calculating Total Accruals (TA):

$\mathrm{NI}_{\mathrm{it}} \quad$ : net income of firm $\mathrm{i}$ in period $\mathrm{t}$

$$
T A_{i t}=N I_{i t}-C F O_{i t}
$$

$\mathrm{CFO}_{\text {it }}$ : cash flow from operation of firm $\mathrm{i}$ in period $\mathrm{t}$

Determination of regression coefficients (Dechow et al., 1995):

$$
T A_{i t} / A_{i t-1}=\beta_{1}\left(1 / A_{i t-1}\right)+\beta_{2}\left(\Delta \operatorname{Rev}_{i t} / A_{i t-1}-\Delta \operatorname{Rec}_{i t} / A_{i t-1}\right)+\beta_{3}\left(P P E_{i t} / A_{i t-1}\right)+\mathrm{e}_{i t}
$$

$\Delta \operatorname{Rev}_{\text {it }}$ : Revenue of firm $\mathrm{i}$ in period $\mathrm{t}$ min revenue of firm in period $\mathrm{t}-1$

$\Delta \operatorname{Rec}_{i t}$ : Receivable of firm $\mathrm{i}$ in period $\mathrm{t}$ min receivable of firm in period $\mathrm{t}-1$

$\mathrm{PPE}_{\mathrm{it}}$ : Property, plan, and equipment (gross tangible fixed assets) of firm $\mathrm{i}$ in period $\mathrm{t}$

$\mathrm{A}_{\mathrm{it}-1} \quad$ : Total company assets $\mathrm{i}$ in period $\mathrm{t}-1$ (beginning of year)

$\mathrm{e}_{\mathrm{it}} \quad$ : Error in term of firm $\mathrm{i}$ in period $\mathrm{t}$

$\beta \quad$ : Regression coefficient

Calculate the value of Non Discretionary Accruals (NDA) from the regression coefficient The regression performed in (2) produces the coefficients $\beta 1, \beta 2$ and $\beta 3$. The coefficients $\beta 1, \beta 2$, and $\beta 3$ are then used to predict non discretionary accruals.

$$
N D A_{i t}=\beta_{1}\left(1 / A_{i t-1}\right)+\beta_{2}\left(\Delta \operatorname{Rev}_{i t} / A_{i t-1}-\Delta \operatorname{Rec}_{i t} / A_{i t-1}\right)+\beta_{3}\left(P P E_{i t} / A_{i t-1}\right.
$$

$\mathrm{NDA}_{\mathrm{it}}$ : Non-discretionary accruals of firm $\mathrm{i}$ in period $\mathrm{t}$

Calculating the value of Discretionary Accruals (DA):

$\mathrm{DA}_{\mathrm{it}} \quad$ : Discretionary accruals of firm $\mathrm{i}$ in period $\mathrm{t}$

$$
D A_{i t}=T A_{i t} / A_{i t-1}-N D A_{i t}
$$

\subsection{Measuring of Disclosure of Financial Report}

The voluntary disclosure item consists of 33 items. The list of disclosure items used in this study generally refers to the research of Wallace et al. (1994), Meek et al. (1995), Fitriany (2001) and Subiyantoro (1997) as used by (Benardi et al., 2008), where the scoring rules for disclosure indexes are as follows: 1) Scoring for each disclosure item is carried out in a dichotomy, where the disclosed item is given 1. If the item is not disclosed given 0.2 ) The score obtained by each company is added to get the total score.

3) Calculation of disclosure index (IP) for each company is done by dividing the total score of each company with the expected total score.

\subsection{Measuring of Managerial Ability}

In measuring managerial ability, researchers use the DEA (Data Envelopment Analysis) method. Basically the DEA model is to compare input and output data from an organization or company (Decision Making Unit, DMU) with other input and output data in a similar DMU. This comparison is done to get a value of efficiency. Efficiency is one of the parameters for measuring the performance of an organization. The output used is sales. Sales are used as output because sales represent the nominal value of the company's products which is the fundamental output of the company. While the items that are used as input are very important inputs to produce output in the form of sales. The inputs are total assets, total employment, DCI (Days COGS In Inventory), and DSO (Days Sales Outstanding).

\subsection{Measuring of Audit Quality}

Auditor quality in this study is defined as the perception of users of audited financial statements about KAP auditing financial statements. Audit quality is proxied by accounting firms size, namely large (Big Four) and small (non-Big Four) accounting firms. Audit quality is measured using a dummy variable with a value of 0 for high-quality auditors (Big Four) and value 1 for low-quality auditors (non-Big Four).

Model 1 in this test uses multiple linear regression analysis techniques. This is done to test the direct effect of independent variable on the dependent variable. Multiple regression analysis uses a significance level at the level of 5\% $(\alpha=0.05)$. Testing model 2 uses data analysis techniques Moderated Regression Analysis (MRA) which maintains the integrity of the sample and provides a basis for controlling the influence of moderator variables (Ghozali, 2016).

\section{Result Discussion}

Testing of Model 1 was conducted to determine the effect of independent variable on dependent variable, this test used multiple linear regression analysis techniques. The test results are shown in Table 1 as follows: 
Tabel 1. Model 1 (Multiple Regression Analysis)

\begin{tabular}{|c|c|c|c|}
\hline \multirow{3}{*}{ (Constant) } & Unstandardized coefficients & \multirow{2}{*}{$\mathrm{T}$} & \multirow{2}{*}{ Sig. } \\
\hline & B & & \\
\hline & 2,258 & 16,965 & 0,000 \\
\hline LK (Disclosure of Financial Report) & $-0,372$ & $-2,914$ & 0,004 \\
\hline KM (Managerial Ability) & 0,003 & 1,081 & 0,281 \\
\hline KA (Audit Quality) & 0,064 & 0,546 & 0,585 \\
\hline Sig. F & 0,018 & & \\
\hline Adjusted R Square & 0,219 & & \\
\hline
\end{tabular}

Source: Primary data, 2018

Based on Table 1, regression equation as follows:

$$
M L=2,258-0,372 L K+0,003 K M+0,064 K A+\varepsilon
$$

The results obtained from the unstandardized coefficient LK are negative value of 0.372 with a signification value of 0.004 smaller than $\alpha=0.05$, which means that the LK partially had positive affects on earnings management. Annual report is a management responsibility for stakeholders, and the use of financial reporters is used to determine the company's performance and manager's performance. The results of this study are in line with agency theory, the existence of information asymmetry can cause a situation where shareholders have less information than management makes managers tend to be involved in opportunistic behavior. The understanding of a financial statement user is based on the level of disclosure of financial statements and also to find out the company's financial position during the reporting period, then an increase in financial statements will reduce information asymmetry, ultimately causing the manager's flexibility to reduce earnings management. If the level of disclosure of financial reported get hinghed, then the practice of earnings management decreased.

The variable $\mathrm{KM}$ is positive that is equal to 0.003 with a significance value of 0.281 greater than $\alpha=0.05$, which means that partially KM has no effect on earnings management. The ability or not of a manager to be worthy of being called to have high managerial abilitys depends on his ability to make accounting decisions that bring the company to be more efficient. Circumstances if the contract conditions are efficient in agency theory are not met, in other words, there is information asymmetry and uncertain returns, this makes managers who have high ability and experience will use their expertise to tend not to show real company information to users. financial statements and focus more on the contents of the financial statements on the personal reasons of the maker of the financial statements (in this case the manager in question). There are conditions that make managers unwilling to be honest in disclosing financial statements, for example in terms of the profit presented in the financial statements is not in accordance with the economic reality at the time concerned. The conditions that are intended are outside this research, so that even though the managers who were the samples in this study were managers who had high managerial abilitys, this was not the reason for the decrease or disappearance of earnings management practices.

The results showed a significance value of $F$ is 0.018 smaller than $\alpha=0.05$, which means that the model used in this study is fit (fit). This shows that LK, KM, and KA are jointly able to predict or explain earnings management. The value of Adjusted R Square is 0.219 . This shows that earnings management can be explained by financial statement disclosure, managerial abilitys, and audit quality by 21.9 percent, while the remaining 78.1 percent is represented by other factors not listed in this study.

Table 2. Model 2 (Moderated Regression Analysis)

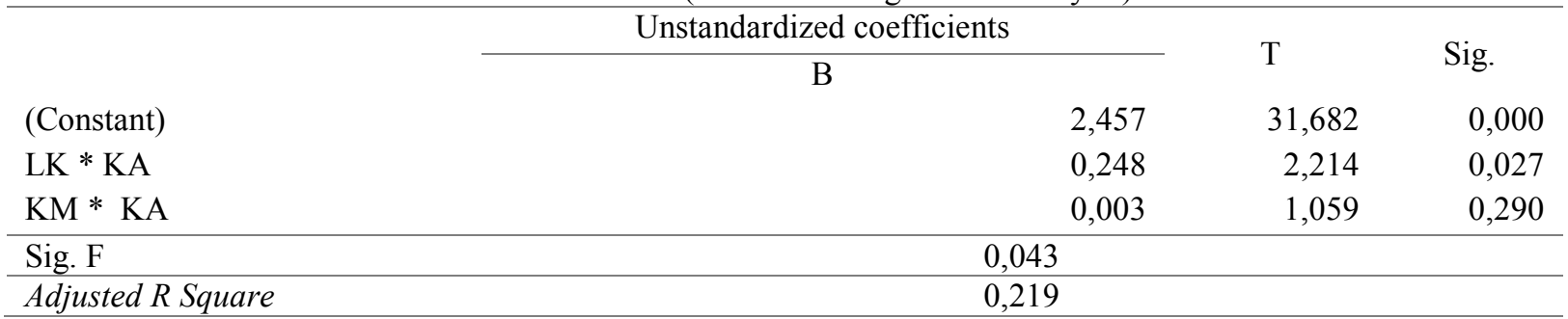

Source: Primary data, 2018

Based on the test results in Table 2, the regression equation is obtained as follows:

$$
M L=2,457-0,372 L K+0,003 K M+0,064 K A+0,248 L K^{*} K A+0,0003 K M * K A+\varepsilon
$$

Table 2. shows the results that $\mathrm{H}_{3}$ is accepted and $\mathrm{H}_{4}$ is rejected. If $\beta_{1}$ is negative, significant or not, and $\beta_{4}$ is positive, the moderating variable weakens the influence of X1 on Y (Utama, 2016). The negative standardized coefficient LK value is $-0,372$ and the unstandardized coefficient of LK interaction and KA are significant positive value 0,248 means that audit quality as a moderating variable weakened the effect of the level of financial statement disclosure on earnings management, but unable to moderate the influence of managerial skills on earnings management. 
At the time the financial statements audited by a qualified auditor will affect the level of disclosure of financial statements better than audited by less qualified auditors. Auditing reports that have high quality will affect the level of financial statement disclosure in earnings management. Audits carried out by Big Four Public Accountants are more likely to detect earnings management. External auditors are expected to find and disclose manipulations in financial statements. A quality audited financial report can reduce earnings management, so that shareholders are confident in their investment decisions.

One of the objectives of auditing financial statements is to suppress information asymmetry, but in reality this has not eliminated earnings management practices. The main factor for this is the assumption that the audit process is not intended to seek earnings management, an auditor cannot provide a statement that the financial statements are wrong or correct, an auditor can only provide a reasonable opinion or not a financial statement. So it can be concluded, the existence of Big Four accounting firms is only as an increase in the credibility of the financial statements produced by management, reducing some transactions that are not in accordance with the SA (Auditing Standards), so that it can produce a fairly reliable audited report.

As for other factors that are more important why auditee reports cannot show earnings management is the relationship between management and mutual trusting firms. A manager needs the auditor to increase the credibility of the financial statements he produces, and often those who choose the accounting firms to conduct the audit process are the manager himself. This condition makes the auditing process standard carried out by accounting firms not too tight so that the audit report results are not optimal. There is a feeling of worry because of the principle of dependence, the auditor has a feeling of hesitation when conducting checks that are too tight, the auditor assumes that he will lose his client. This is indisputable because sometimes companies (management) prefer auditors who are not too strict in conducting supervision or conducting an audit process on the financial statements they produce.

\section{Conclusion and Recomendation}

Based on (1) hypothesis and (2) the results of testing, it can be concluded four important things. First, the effect of the variable discloure of financial report on earnings management is negative. Companies that conduct full disclosure will reduce earnings management practices. The lower level of disclosure of financial statements will facilitate earnings management practices. In addition to these conditions, things found in this study are managerial ability that do not affect earnings management. There are conditions where high managerial ability do not give effect to earnings management practices that may occur in the company. It is suspected that there are other factors that affect earnings management more than managerial ability.

Furthermore, the quality of the audit has weakened the influence of the level of disclosure of financial statements on earnings management. Big Four accounting firms is able to detect earnings management within a company. If the level of high financial statement disclosure can reduce the opportunistic actions of managers who prioritize their personal interests rather than the interests of the company, this is what triggers earnings management practices. Supported by an audited report conducted by a quality Big four, it will strengthen the influence of the level of financial statement disclosure in reducing the possibility of earnings management practices. However, good audit quality cannot strengthen or weaken the relationship between managerial ability in earnings management, this does not guarantee a theory which states that companies that have a capable manager can reduce earnings management practices.

The existence of asymmetric information causes the disclosure of financial statements not to approach full disclosure. This can mean efficient contracts are not implemented so that the agent and principal relationship in this case the manager and shareholders are based on information asymmetry, and management uses the flexibility it has to make earnings management. The auditor has the obligation to provide an opinion as limited as is reasonable or unnatural disclosure of financial statements, not true or false of the financial statements. Therefore the audited report produced by a qualified accounting firms expected to detect material misstatement, errors in accounting records that can be used by managers for their personal interests, and the selection of accounting policies that are used as loopholes for managers who are opportunistic, so that the financial statements presented by the company are more reliable. and trustworthy.

Managers who do not meet efficient contractual requirements in agency theory tend to cause uncertain information asymmetries and returns. This makes managers with high ability and experience will use their expertise to tend not to show actual company performance information to external parties.

There are some limitations in this study that can be revealed by researchers, and this requires the development of further research concepts and improvements to this research, so that later this research will be useful for future researchers. The suggestions that can be conveyed by researchers are as follows: (1) emphasis on company managers to pay more attention to the concept of good corporate governance in order to reduce the phenomenon of earnings management practices; (2) emphasis for future researchers to use a profit calculation that is far more accurate than the Jones model used by researchers today. An example that can be suggested by researchers is the calculation of earnings management per industry so that later interpretation of results can be 
done per industry; (3) further research should be able to use other measurement indicators that can affect earnings management, other independent variables outside the current research model. For example, further research can use other good corporate governance mechanisms in addition to managerial abilitys, such as managerial ownership or frequency of audit co-meeting meetings.

\section{References}

Augustine O. Okolie. (2013). Audit Quality and Accrual - Based Earnings Management of Quoted Companies in Nigeria. IOSR Journal of Economics and Finance, 16(1), 07-16.

Benardi, M., Sutrisno, \& Assih, P. (2008). Faktor-Faktor yang Memengaruhi Luas Pengungkapan dan Implikasinya Terhadap Asimetri Informasi (Studi Pada Perusahaan-Perusahaan Sektor Manufaktur yang Go Public di Bursa Efek Indonesia). Simposium Nasional Akuntansi XII Palembang.

Consoni, S., Colauto, R. D., \& Lima, G. A. S. F. de. (2017). Voluntary disclosure and earnings management: evidence from the Brazilian capital market. Revista Contabilidade \& Finanças, 28(74), 249-263.

De Angelo, L. E. (1981). Auditor Size and Audit Quality. Journal of Accounting and Economics, 3(May)

Demerjian, P., Lewis, M., \& Mcvay, S. (2012). Managerial Ability and Earnings Quality. The Accounting Review, 88(2).

Demerjian, P. R., Lev, B., Lewis, M. F., \& McVay, S. E. (2013). Managerial ability and earnings quality. Accounting Review, 88(2),

Endrianto, W. (2010). Analisa Pengaruh Penerapan Basel Dan Good Corporate Governance Terhadap Manajemen Risiko Pada PT. Bank Negara Indonesia (Persero) Tbk.

Gerayli, M. S., Yanesari, A. M., \& Ma'atoofi, A. R. (2011). Impact of Audit Quality on Earnings Management: Evidence from Iran. International Research Journal of Finance \& Economics,

Ghozali, P. D. H. ima. (2016). Aplikasi Analisis Multivariete dengan program IBM SPSS 23. In IBM SPSS 23 (p. $52)$.

Islam, M. A., Ali, R., \& Ahmad, Z. (2011). Is Modified Jones Model Effective in Detecting Earnings Management? Evidence from A Developing Economy. International Journal of Economics and Finance, $3(2)$

Isnugrahadi, I., \& Kusuma, I. W. (2009). Pengaruh Kecakapan Managerial Terhadap Managemen Laba Dengan Kualitas Auditor Sebagai Variabel Pemoderasi. Simposium Nasional Akuntansi XII, 1-25.

Jatiningrum, C., Abdul-hamid, M. A., Muse, O., \& Popoola, J. (2016). The Impact of disclosure quality on corporate governance and earnings management: Evidence from companies in Indonesia. International Journal of Economics and Finance Issues, 6(S4), 118-125.

Jensen, C., \& Meckling, H. (1976). Theory of the Firm: Managerial Behavior , Agency Costs and Ownership Structure. Journal of Financial Economics, 3, 305-360.

Kirana, R., \& Hasan, A. (2016). Pengaruh Tingkat Pengungkapan laporan Keuangan, Kecakapan Manajerial dan Risiko Ligitasi Terhadap Manajemen Laba dengan Kualitas Audit Sebagai Variabel Pemoderasi (Raisa Kirana, Amir Hasan \& Hardi). Jurnal Akuntansi, 4(2), 189-205.

Kurniawati, N. (2011). Pengaruh Tingkat Pengungkapan Laporan Keuangan Terhadap Manajemen Laba Dengan Kualitas Audit Sebagai Variabel Pemoderasi. Jurnal Universitas Brawijaya., 1-28.

Li, H. (2015). Managerial Ability and Internal Control Quality: Evidence from China. International Journal of Financial Research, 6(2).

Nuryaman. (2009). Pengaruh Konsentrasi Kepemilikan, Ukuran Perusahaan dan Mekanisme Corporate Governance Terhadap Manajemen Laba. Simposium Nasional Akuntansi XI Pontianak. Jurnal Akutansi Dan Keuangan Indonesia, 6(1), 89-116.

Purwanti, R. B., \& Rahardjo, S. N. (2012). Pengaruh Kecakapan Manajerial, Kualitas Auditor, Komite Audit, Firm Size Dan Leverage Terhadap Earnings Management (Studi Empiris Pada Perusahaan Manufaktur Yang Terdaftar Di BEI Tahun 2008-2010). Diponegoro Journal of Accounting, 1(1), 1-12.

Riahi, Y., \& Arab, M. B. E. N. (2011). Disclosure frequency and earnings management: An analysis in the Tunisian context. Journal of Accounting and Taxation, 3(July), 47-59.

Septiana, H. (2013). Pengaruh Kecakapan Manajerial Dan Kepemilikan Manajerial Terhadap Praktik Manajemen Laba (Studi Empiris Pada Perusahaan Manufaktur Yang Terdaftar Di Bursa Efek Indonesia Tahun 2009-2011). Jurnal Universitas Brawijaya., vol 2 no 1.

Sukartha, I. M. (2008). Pengaruh Manajemen Laba, dan Kepemilikan Manajerial pada Kesejahteraan Pemegang Saham Perusahaan Target Akuisisi. Jurnal Ilmiah Akuntansi Dan Bisnis Universitas Udayana, 1(3), 1-25.

Utama, M. S. (2016). Aplikasi Analisis Kuantitatif. Denpasar: CV Satra Utama.

Utami, R., \& Syafruddin, M. (2013). Manajemen Laba Dengan Kualitas Auditor Sebagai Variabel Pemoderasi. Diponegoro Journal Of Accounting, 2, 1-11.

Uwuigbe, U. (2017). Disclosure Quality And Earnings Management Of Selected Nigerian Banks. Journal of Internet Banking and Commerce, 22(May). 
Velayutham, E. (2014). Voluntary disclosure of greenhouse gas emissions, corporate governance and earnings management: Australian evidence. University Of Southern Queensland.

Wicaksono, A. B., \& Yuyetta, E. N. A. (2013). Pengaruh Kecakapan Manajerial Terhadap Praktik Manajemen Laba Dengan Corporate Governance Sebaga Variabel Pemoderasi. Diponegoro Journal Of Accounting, 2(4), $1-11$.

Wirawati, N. G. P., Asri Dwija Putri, I. G. A. M., \& Pradnyantha Wirasedana, I. W. (2018). Pengaruh kebijakan deviden, kompensasi, dan leverage pada manajemen laba di perusahaan manufaktur. Jurnal Krisna: Kumpulan Riset Akuntansi, 10(1), 32-40. 